\title{
Do captive-born greater rheas Rhea americana Linnaeus (Rheiformes, Rheidae) remember antipredator training?
}

\author{
Cristiano S. de Azevedo \& Robert J. Young
}

\begin{abstract}
Pós-graduação em Zoologia de Vertebrados, Conservation, Ecology and Animal Behaviour Group, Pontifícia Universidade Católica de Minas Gerais. Avenida Dom José Gaspar 500, Prédio 41, Coração Eucarístico, 30535-610 Belo Horizonte, Minas Gerais, Brasil. E-mail: cristianoroxette@yahoo.com; robyoung@pucminas.br
\end{abstract}

\begin{abstract}
The antipredator training is a powerful tool now being used to help the reintroduced animals to recognise and escape from their predators. Testing the memory capacity of the animals after antipredator training is important to evaluate if the application of the training is worthwhile. A group of 15 captive-born greater rheas was studied at Belo Horizonte Zoo. Eight birds were antipredator trained and seven birds were not. After the end of the antipredator training sessions, we run four memory tests at 40,55, 70 and 88 days after training was completed. The memory tests consisted of showing a predator model to the rheas and recording their behavioural responses. It was measured the capacity of antipredator information storage, the influence of the group size on the behaviour of the birds and the influence of the antipredator training on the elicitation of the correct behavioural responses of the birds when confronted by a predator. The results showed that the rheas retained predator recognition for almost three months, that the group size affected the responses of the birds (more defence behaviours expressed when tested alone) and that the antipredator training is essential to elicit the adequate antipredatory responses, since untrained birds behaved in a tranquil manner when confronted by a predator model. We concluded that antipredator training is worthwhile for future reintroduction programs for greater rheas, since their memory capacity is considerable.
\end{abstract}

KEY WORDS. Aves; conservation; memory test; naive birds; reintroduction.

RESUMO. Emas Rhea americana Linnaeus (Rheiformes, Rheidae) se lembram do treinamento anti-predação? O treinamento anti-predação é uma ferramenta poderosa usada atualmente para ajudar os animais reintroduzidos a reconhecer e escapar de seus predadores. Testar a capacidade de memória dos animais após o treinamento é importante para se avaliar a validade de sua aplicação. Um grupo de 15 emas nascidas em cativeiro foi estudado no zoológico de Belo Horizonte. Oito aves foram treinadas contra predadores e sete não. Após o término dos treinamentos, foram realizados quatro testes de memória após 40, 55, 70 e 88 dias. Os testes de memória consistiam em apresentar um modelo de predador para as emas e anotar as respostas comportamentais exibidas. Foram medidas a capacidade de memória das aves, a influência do tamanho do grupo no comportamento das aves e a influência do treinamento anti-predação na estimulação de respostas comportamentais adequadas. Os resultados mostraram que as emas retiveram a capacidade de reconhecimento do predador por quase três meses após o término dos treinamentos, que o tamanho do grupo afeta as respostas das aves (mais comportamentos de defesa quando sozinhas) e que o treinamento anti-predação é essencial para estimular uma resposta comportamental adequada, uma vez que o grupo não treinado se comportou tranqüilamente perante o predador. Conclui-se que o treinamento anti-predação é válido para futuros programas de reintrodução de emas, uma vez que a capacidade de memória dessas aves é considerável.

PALAVRAS CHAVE. Aves cativas; conservação; reintrodução; teste de memória.

Greater rheas, Rhea americana (Linnaeus, 1758), are flightless South American birds (belonging to the ratites group) that are found in Brazil, Argentina, Uruguay, Paraguay and Bolivia (DEL Hoyo et al. 1992), in the cerrado and open grass regions (PERRINS $\&$ Middleton 1998). Many authors report the disappearance of wild populations (DANI 1993, CoDENotTI et al. 1995, CoDenotTI \& Alvarez 2000, Fernadez et al. 2003), the species being classified by the IUCN as near threatened (IUCN 2004). Hunting, habitat loss, egg destruction by crop burnings and agricultural machinery, and predation by native and alien species are responsible for the 
reduction of the wild populations (DANI 1993). The major rhea predators are bush dog, Speothos venaticus Lund, 1842); manedwolf, Chrysocyon brachyurus, Illiger, 1811; jaguar, Panthera onca Linnaeus, 1758, tegu lizard, Tupinambis teguixin Linnaeus, 1758; feral dogs, Canis familiaris Linnaeus, 1758; and some birds of prey (Del Hoyo et al. 1992, DANi 1993, Sick 1997).

One management procedure used to avoid the disappearance of species in the wild is reintroduction (KLEIMAN 1989). Many reintroduction programs have failed to establish viable populations because the animals released were predated (BЕсK et al. 1991, SHORT et al. 1992, Miller et al. 1994). For example, greater rheas reintroduced in the State of Minas Gerais, Brazil, died due to feral dog attacks (Ângela Faggioli, BH Zoo Biologist, pers. comm.).

Captive-born animals usually lose their abilities to recognise predators when isolated from them for many generations (GRIFFIN et al. 2000). Depending on the isolation time, some species-specific defence reaction (SSDR) precursors remain in the memory system of the animal, allowing conservation biologists to apply classical conditioning techniques to increase antipredatory responses (GRIFFIN et al. 2000). Antipredator training has been used to enhance the responses of naive animals to their predators and the results are encouraging (Miller et al. 1994, Maloney \& McLean 1995, Richards 1998, McLean et al. 1999). Social training is suggested for animals that normally live in groups (CURIO 1988, MineKA \& CoOK 1988) since the learning processes increases with the social contact (Morgan 1972, Curio et al. 1978, Herzog \& Hopf 1984, Mathis et al. 1996, Lima \& BedneKofF 1999, Kelley et al. 2003).

It is important to evaluate the memory capacity of animals that are submitted to antipredatory training, since its effects are extremely variable. Cś́NYI et al. (1989), studying goldfishes, Carassius auratus Linnaeus, 1758, found a memory capacity of three months, which is considerable since this species has a life-span of only one year. FERRARI (1996) cited long-term memory for common pigeons, Columba livia Gmelin, 1789. Knowledge about how long the information acquired during antipredator training remains stored in the memory of the animal is important to evaluate the cost-benefits of antipredator training.

Antipredatory training has never been applied to ratite birds, and little is know about their memory capacity. A group of eight greater rheas was trained against predation. Our goal was to evaluate their capacity for predator recognition (memory) after antipredator training sessions, and to investigate the number of memory testing sessions that are necessary to habituate the behavioural responses of the birds to a predator model.

\section{MATERIAL AND METHODS}

\section{Animals, housing and maintenance}

We studied 15 greater rheas (eight males and seven females), all bred at Belo Horizonte Zoo (BH Zoo). Eight birds were divided into two trained-groups (group one, G1, and group two, G2), with four birds each. These groups were housed in enclosures $15 \mathrm{~m}$ long and $15 \mathrm{~m}$ wide. Seven birds were housed in an enclosure $28 \mathrm{~m}$ long and $16 \mathrm{~m}$ wide; this group was not trained (control group, CG). All rheas received food and water ad libitum and were marked (plastic coloured leg. bands and leg. tattoos) for identification. All birds were handled constantly prior to the experiments.

Rheas were trained in a different enclosure; this was a wire-fenced arena (length $37 \mathrm{~m} \mathrm{X} 8.4 \mathrm{~m}$ wide) screened with a 2-m-high strip of opaque black plastic to isolate the birds visually from their surroundings. A window in one of the long sides of the enclosure allowed the birds to see the predator model, which passed in a corridor adjoining the fence (Fig. 1).

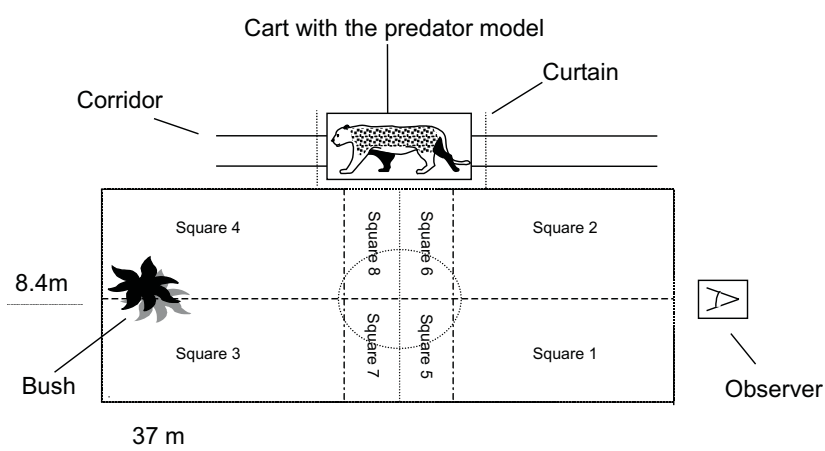

Figure 1. Test arena used during antipredator training sessions and memory tests at Belo Horizonte Zoo.

\section{Antipredator training}

Antipredator training sessions were based on the methodology described by GRIFFIN et al. (2001): the stimulus (predator) appeared to the animals for about 3-5 s before a human wearing a costume and carrying a net entered the enclosure and began a simulated capture procedure (aversive experience). The appearance of the stimulus predicted the onset of the capture event. Birds were chased back and forth four times in the enclosure. The human exited the arena through the hide and the stimulus was passed through view of the birds again for about 3-5 s. The whole conditioning procedure lasted about $60 \mathrm{~s}$. The costume had the objective of camouflaging the human silhouette, avoiding the rheas to pair the predators with the human being.

We used as predators a taxidermized jaguar, a chair (used as a control test) and a live dog. Each animal received 15 training sessions, separated equally among the models, from June to September 2003 (Azevedo \& Young 2006).

\section{Ethogram}

The behaviours recorded during the tests were: vocalizing, alert, walking, pacing, inactive, foraging, running in zigzags, running straight, squatting down and flattening the body against the ground, hiding behind the tree, and jumping. The behaviours: alert, pacing, running in zigzags, squatting down and flattening the body against the ground, jumping, and hid-

Revista Brasileira de Zoologia 23 (1): 194-201, março 2006 
ing behind the tree, were considered to indicate stress, fear, vigilance or defence. The behaviours: walking, inactive, vocalising, foraging, and other behaviours, were considered to indicate that the birds were relaxed (CODENOTTI et al. 1995).

\section{Memory tests}

Fourteen memory tests were applied to the trained-groups and untrained (control group); both trained-groups (G1 and G2) were subdivided into four smaller groups, with two birds each. These new groups were created randomly. The final groups were: group one - rheas number three and seven; group two rheas number four and five; group three - rheas number one and eight; group four - rheas number two and six. Each group was tested separately in the same arena of the antipredator training sessions (excluding the control group which was tested in its maintenance enclosure). This subdivision allowed us to evaluate the memory capacity of the rheas, to find out the number of tests necessary for habituation of the animals to a model predator and to evaluate if the number of birds in a group influenced their antipredatory responses, by comparing the responses of the rheas in the memory tests with the responses showed during the antipredator training sessions. For statistical analysis, the groups were regrouped into trained and untrained groups.

Memory tests consisted of showing the jaguar model to the trained birds, without pairing it to an aversive stimulus (i.e., they were not chased by the costumed human carrying a net). Each test was video recorded and lasted 18 minutes: two minutes immediately prior to stimulus appearance (baseline), one minute during the stimulus presentation (predator model), and 15 minutes after the stimulus has disappeared from view.

The memory tests were conducted in accordance with the sequence in table I: group one and control group were tested four times each, group two was tested three times, group three was tested two times, and group four was tested one time. Tests were run with $40,55,70$ and 88 days after the end of antipredator training.

The predator model was presented to the rheas of the control group (i.e., those not submitted to antipredatory training sessions), allowing the comparison between the behavioural responses of trained and untrained groups, although the test was conducted in the maintenance enclosure (the test was not conducted at the test arena because of the difficulties in rhea transportation); the jaguar model was carried to the enclosure and hidden behind a strip of opaque black plastic put on the fence of the enclosure.

\section{Data collection and statistical analyses}

The memory tests were run in August to September 2003; all tests were conducted at 8:00-9:00 am. We recorded the time of individual's reaction to stimulus (latency) and analysed the behavioural responses of the rheas to the jaguar model. We also recorded the region of the enclosure occupied by the rheas in each sampling point and the direction to where the beak
Table I. Schedule of the memory tests applied to trained and untrained groups: (G1) group 1, (G2) group 2, (G3) group 3, (G4) group 4, (CG) control group.

\begin{tabular}{ccccc}
\hline $\begin{array}{c}\text { Days after the } \\
\text { end of the } \\
\text { antipredator } \\
\text { training } \\
\text { sessions }\end{array}$ & 40 & 55 & 70 & 88 \\
\hline & 3 e $7(\mathrm{G} 1)$ & 3 e $7(\mathrm{G} 1)$ & 3 e $7(\mathrm{G} 1)$ & 3 e $7(\mathrm{G} 1)$ \\
& 4 e $5(\mathrm{G} 2)$ & 4 e $5(\mathrm{G} 2)$ & 4 e $5(\mathrm{G} 2)$ \\
Rheas & & & 1 e $8(\mathrm{G} 3)$ & 1 e $8(\mathrm{G} 3)$ \\
& $\mathrm{CG}$ & $\mathrm{CG}$ & $\mathrm{CG}$ & $\mathrm{CG}$ \\
\hline
\end{tabular}

was pointed (this kind of information was not collected for control group since it was tested in their maintenance enclosure and not in the test arena like the trained groups). This type of data allowed us to analyse the rate of vigilance showed by the birds during the tests.

Behaviours were quantified, and then statistically analysed using Friedman's non-parametric ANOVA test and Kendall Coefficient of Concordance. The Tukey test was used post-hoc to compare the behavioural responses to the four different time periods, for the groups and for each bird individually. Latencies were recorded using a digital stopwatch; three measures were taken for each bird and the average result was used in the analyses. The percentage of the number of registers in each region of the enclosure and the regions to where the beaks were pointed were calculated. For all statistical analysis, the confidence level was 95\% $(\alpha=0.05)$.

\section{RESULTS}

The behaviours vocalizing, squatting down and flattening the body against the ground, inactive, running in zigzags, jumping and hiding behind the tree were excluded from statistical analysis because either they were not recorded or were seldom recorded.

The Friedman's test revealed a statistical difference between the behaviours of the three groups; only the categories foraging and other behaviours did not differ statistically between the groups. In general, the control group expressed more behaviours than the two trained groups; running straight, however, was more exhibited by trained group one. The control group (not trained against predation) showed more "calm behaviours than the other groups, which were more cautions in relation to the predator model (Tab. II).

The mean numbers of behaviours showed by the three groups and by each rhea individually, analysed by each test day, are shown in table III. Rheas of group one were more apprehensive during the tests, displaying more the behaviours alert and running straight. For the rheas of group two, which 
Table II. Mean number of behaviours recorded, standard error and Friedman's ANOVA and Kendall Coefficient of Concordance test for the behaviours displayed by the three groups during the memory tests.

\begin{tabular}{lcccc}
\hline \multicolumn{1}{c}{ Behaviour } & Group 1 & Group 2 & Control-group & Friedman \\
\hline Alert & $35.9 \pm 1.8$ & $36.5 \pm 2.6$ & $144.0 \pm 8.6$ & $18.99^{* *}$ \\
Walking & $16.0 \pm 1.4$ & $20.7 \pm 2.1$ & $206.5 \pm 9.9$ & $41.22^{* *}$ \\
Foraging & $0.4 \pm 0.3$ & - & $1.7 \pm 0.9$ & 0.03 \\
Pacing & $2.3 \pm 0.6$ & $0.9 \pm 0.5$ & $44.0 \pm 5.1$ & $8.01^{*}$ \\
Running straight & $43.4 \pm 1.9$ & $36.8 \pm 2.6$ & $35.8 \pm 4.5$ & $98.96^{* *}$ \\
Other behaviours & $1.2 \pm 0.4$ & $0.9 \pm 0.5$ & $3.0 \pm 1.5$ & 0.04 \\
\hline
\end{tabular}

Groups 1, 2, and control: $\mathrm{N}=928$; Friedman: D.F. $=2 ;(-)$ behaviours not recorded for the group; ${ }^{*} \mathrm{p}<0.01 ;{ }^{* *} \mathrm{p}<0.001$.

were submitted to two tests (70 and 88 days), the birds behaved nervously in relation to the predator, displaying more of the behaviours running straight and alert. Rheas two and six, which were submitted only to one test (88 days), displayed the behaviour alert more than the other behaviours (Tab. III).

Rheas of the control group behaved differently in comparison to the two trained groups. These birds, during the two first tests (40 and 55 days), exhibited more times behaviours such as alert. In the two last tests (70 and 88 days), these rheas behaved in a tranquil manner, displaying the behaviour walking much more times than the other behaviours (Tab. III).

The Friedman test revealed statistical differences between the days of application of the memory tests for the three groups
(Tab. III). For group one, the behaviours walking and running straight showed statistical differences between all tests. Tukey tests showed that the behaviour walking was more expressed in the first test (40 days), diminishing significantly until the third test (70 days), then increasing again in the last test ( 88 days). The behaviour running straight increased until it reached its maximum in the third test (70 days), then diminishing significantly in the fourth test ( 88 days). Alert showed a tendency to reduce across the tests, with the lowest expression in the third test (70 days), but increased in the fourth test ( 88 days).

For group two, the behaviours alert, walking and running straight showed differences statistically significant; for the two first behaviours, the tendency was to increase the number of

Table III. Comparison between the behaviours of the three rhea groups, analysing the four different days of memory test, according to the Friedman's ANOVA and Kendall Coefficient of Concordance.

\begin{tabular}{|c|c|c|c|c|c|c|}
\hline \multirow{2}{*}{ Rhea groups } & \multirow{2}{*}{ Behaviours } & \multicolumn{4}{|c|}{ Tests (days) } & \multirow{2}{*}{ Friedman } \\
\hline & & 40 & 55 & 70 & 88 & \\
\hline \multirow[t]{6}{*}{ Group 1} & Alert & $50.0 \pm 4.7$ & $37.5 \pm 3.2$ & $25.9 \pm 3.3$ & $34.5 \pm 3.6$ & $9.61^{* *}$ \\
\hline & Walking & $32.8 \pm 4.4$ & $22.4 \pm 2.7$ & $1.2 \pm 0.8$ & $10.9 \pm 2.4$ & $14.76^{* *}$ \\
\hline & Foraging & $2.6 \pm 1.5$ & - & - & - & - \\
\hline & Pacing & $3.5 \pm 1.7$ & $0.9 \pm 0.6$ & $4.0 \pm 1.5$ & $1.7 \pm 1.0$ & 0.14 \\
\hline & Running straight & $5.2 \pm 2.1$ & $37.1 \pm 3.2$ & $69.0 \pm 3.5$ & $51.7 \pm 3.8$ & $73.45^{* * *}$ \\
\hline & Other behaviours & $6.0 \pm 2.2$ & - & - & $0.6 \pm 0.6$ & 0.35 \\
\hline \multirow[t]{5}{*}{ Group 2} & Alert & - & - & $8.6 \pm 2.6$ & $50.4 \pm 3.3$ & $49.14^{* * *}$ \\
\hline & Walking & - & - & $7.8 \pm 2.5$ & $27.2 \pm 2.9$ & $12.52^{\star * *}$ \\
\hline & Pacing & - & - & - & $2.6 \pm 1.5$ & - \\
\hline & Running straight & - & - & $73.3 \pm 4.1$ & $18.5 \pm 2.6$ & $7.57^{* *}$ \\
\hline & Other behaviours & - & - & $2.6 \pm 1.5$ & - & - \\
\hline \multirow[t]{6}{*}{ Control group } & Alert & $165.5 \pm 12.4$ & $174.1 \pm 19.0$ & $67.2 \pm 12.6$ & $169.0 \pm 19.6$ & $22.00^{\star * *}$ \\
\hline & Walking & $144.8 \pm 18.8$ & $129.3 \pm 16.1$ & $250.0 \pm 17.4$ & $301.7 \pm 17.1$ & $38.32^{\star * *}$ \\
\hline & Foraging & $3.5 \pm 2.4$ & - & $3.5 \pm 2.4$ & - & 0.16 \\
\hline & Pacing & $84.5 \pm 13.7$ & $29.3 \pm 7.8$ & $31.0 \pm 9.9$ & $31.0 \pm 6.6$ & $8.84^{*}$ \\
\hline & Running straight & - & $15.5 \pm 7.7$ & $29.3 \pm 8.2$ & $98.3 \pm 10.0$ & $39.58^{* * *}$ \\
\hline & Other behaviours & $6.9 \pm 5.4$ & - & $5.2 \pm 2.9$ & - & 0.27 \\
\hline
\end{tabular}

(-) Behaviours not recorded; ${ }^{*} \mathrm{p}<0.05 ;{ }^{* *} \mathrm{p}<0.01$; ${ }^{* * *} \mathrm{p}<0.001$; groups 1,2 , and control: $\mathrm{N}=232$. 
occurrences (higher occurrence value for the fourth test); for the last behaviour, the tendency was the reduction of occurrences (lesser value for the fourth test - 88 days) (Tab. III).

For the control group, there was no statistical difference between the memory tests for the behaviours foraging and "other behaviours. For the other behaviours, however, we found statistical differences although these differences had not happen between all tests. For the behaviour walking, we found the tendency was to increase; for the behaviour pacing, the tendency was to decrease and for the behaviour running straight, the tendency was to increase across the tests (Tab. III).

The Friedman test was also applied to evaluate if the behaviours expressed by the rheas individually differed between the tests (Tab. IV). We found statistical differences between the tests for many rheas and for different behaviours but with no definite pattern.

Trained rheas (G1 and G2) pointed their beaks mostly to region four (the front of the enclosure) and used mostly square three (back of the test arena, opposite side to the predator appearance) (Tab. V). Analysing each bird individually, we noted that only rhea six used mostly square one (the front of the enclosure, left side of the observer). Also rhea two, that used mostly squares one and three (in the same proportion), differed from the pattern found for the rest of the trained rheas (Tab. V).

Rheas of group one reacted to the predator model faster in the third test, rheas of group two reacted faster to the predator model in the last memory test and rheas of the control group responded faster to the predator model in the second memory test. Although the reacting time varied along the days, a tendency of increasing in the reaction to the predator model can be observed for all groups. Each individual, however, responded differently, with some reacting equally quickly in all days (rhea eight), some reacting faster across the tests (rhea five) and some reacting slower across the tests (rhea three) (Tab. VI).

Table IV. Comparison between the number of behaviours of the rheas, analysing the four different days of memory test, according to the Friedman's ANOVA and Kendall Coefficient of Concordance.

\begin{tabular}{|c|c|c|c|c|c|c|}
\hline \multirow{2}{*}{ Rhea } & \multirow{2}{*}{ Behaviours } & \multicolumn{4}{|c|}{ Tests (days) } & \multirow{2}{*}{ Friedman } \\
\hline & & 40 & 55 & 70 & 88 & \\
\hline \multirow[t]{5}{*}{3} & Alert & $44.8 \pm 6.6$ & $36.2 \pm 6.3$ & - & - & 0.86 \\
\hline & Walking & $43.1 \pm 6.6$ & $60.3 \pm 6.5$ & - & - & 1.63 \\
\hline & Foraging & $1.7 \pm 1.7$ & - & - & - & - \\
\hline & Pacing & - & $1.7 \pm 1.7$ & - & - & - \\
\hline & Other behaviours & - & $10.3 \pm 4.0$ & - & - & - \\
\hline \multirow[t]{3}{*}{4} & Alert & - & $13.8 \pm 4.6$ & $15.5 \pm 4.8$ & $22.4 \pm 5.5$ & 0.08 \\
\hline & Pacing & - & $1.7 \pm 1.7$ & - & - & - \\
\hline & Running straight & - & $86.2 \pm 4.6$ & $82.8 \pm 5.0$ & $75.9 \pm 5.7$ & 0.51 \\
\hline \multirow[t]{3}{*}{5} & Alert & - & $34.5 \pm 6.3$ & $37.9 \pm 6.4$ & $34.5 \pm 6.3$ & 1.24 \\
\hline & Walking & - & $3.5 \pm 2.4$ & - & $3.5 \pm 2.4$ & 0.08 \\
\hline & Running straight & - & $55.2 \pm 6.6$ & $62.1 \pm 6.4$ & $62.1 \pm 6.4$ & 3.83 \\
\hline \multirow[t]{6}{*}{7} & Alert & $55.1 \pm 6.6$ & $65.5 \pm 6.3$ & $24.1 \pm 5.7$ & $46.6 \pm 6.6$ & $13.00^{* *}$ \\
\hline & Walking & $22.4 \pm 5.5$ & $25.9 \pm 5.8$ & $3.5 \pm 2.4$ & $29.3 \pm 6.0$ & $9.28^{* *}$ \\
\hline & Foraging & $3.4 \pm 2.4$ & - & - & - & - \\
\hline & Pacing & $6.9 \pm 3.4$ & $1.7 \pm 1.7$ & $10.3 \pm 4.0$ & $5.2 \pm 2.9$ & 0.42 \\
\hline & Running straight & $10.3 \pm 4.0$ & $6.9 \pm 6.4$ & $62.1 \pm 6.4$ & $17.24 \pm 5.0$ & $32.11^{* * *}$ \\
\hline & Other behaviours & $1.7 \pm 1.7$ & - & - & $1.7 \pm 1.7$ & 0.03 \\
\hline \multirow[t]{3}{*}{1} & Alert & - & - & $15.5 \pm 4.6$ & $32.8 \pm 6.2$ & 1.35 \\
\hline & Walking & - & - & $13.8 \pm 4.7$ & - & - \\
\hline & Running straight & - & - & $70.7 \pm 6.0$ & $67.2 \pm 6.0$ & 0.05 \\
\hline \multirow[t]{5}{*}{8} & Alert & - & - & $1.7 \pm 1.7$ & $36.2 \pm 6.4$ & $7.78^{\star *}$ \\
\hline & Walking & - & - & $1.7 \pm 1.7$ & $6.9 \pm 6.6$ & $16.55^{\star * *}$ \\
\hline & Pacing & - & - & $5.2 \pm 2.9$ & - & - \\
\hline & Running straight & - & - & $75.9 \pm 5.7$ & $6.9 \pm 3.4$ & $28.59^{\star \star *}$ \\
\hline & Other behaviours & - & - & - & $6.9 \pm 5.4$ & - \\
\hline
\end{tabular}

(-) Behaviours not recorded; ${ }^{*} \mathrm{p}<0.05 ;{ }^{* \star} \mathrm{p}<0.01 ;{ }^{* * *} \mathrm{p}<0.001$; Group 1, 2 and control: $\mathrm{N}=232$. 
Table V. Areas used and directions of beaks for the tested groups and each bird individually on the arena during memory tests. Percentage of the number of records in each area and each beak direction: (I) back of the enclosure, (II) predator area, (III) area opposite spatially to predator, (IV) front of the enclosure. Areas: (1) front of the enclosure, contrary to predator; (2) front of the enclosure, contrary to predator; (3) back of the enclosure, contrary to predator; (4) back of the enclosure, predator area; (5) square 1, in front of the window of predator appearance; (6) square 2, in front of the window of predator appearance; (7) square 3 , in front of the window of predator appearance; (8) square 4 , in front of the window of predator appearance.

\begin{tabular}{|c|c|c|c|c|c|c|c|c|c|c|c|c|}
\hline \multirow{2}{*}{ Rhea } & \multicolumn{4}{|c|}{ Beak directions (\%) } & \multicolumn{8}{|c|}{ Areas of the enclosure used by the rheas (\%) } \\
\hline & $\mathrm{I}$ & II & III & IV & 1 & 2 & 3 & 4 & 5 & 6 & 7 & 8 \\
\hline Group 1 & 30.49 & 9.05 & 22.11 & 36.27 & 9.05 & 1.15 & 57.77 & 0.14 & 10.20 & 0.57 & 21.12 & - \\
\hline 3 & 20.69 & 11.21 & 37.07 & 31.03 & 1.72 & 0.86 & 84.50 & - & 6.03 & 0.86 & 6.03 & - \\
\hline 4 & 37.93 & 8.62 & 14.37 & 39.08 & 16.09 & - & 55.75 & - & 9.19 & - & 18.97 & 0.34 \\
\hline 5 & 33.53 & 14.12 & 14.71 & 37.65 & 0.58 & 2.87 & 57.47 & 0.58 & 8.04 & 0.58 & 29.88 & - \\
\hline 7 & 27.59 & 10.78 & 25.86 & 35.78 & 13.79 & 0.86 & 46.12 & - & 14.66 & 0.86 & 23.71 & - \\
\hline Group 2 & 28.61 & 18.07 & 18.68 & 34.64 & 15.80 & 3.74 & 61.21 & 1.72 & 10.92 & - & 6.61 & - \\
\hline 1 & 43.10 & 9.48 & 6.90 & 40.52 & 16.38 & - & 62.07 & - & 12.07 & - & 9.48 & - \\
\hline 2 & 23.21 & 21.43 & 35.71 & 19.64 & 29.31 & 6.90 & 29.31 & - & 25.86 & - & 8.62 & - \\
\hline 6 & 20.37 & 27.78 & 24.07 & 27.78 & 32.76 & 15.52 & 31.03 & - & 15.52 & - & 5.17 & - \\
\hline 8 & 19.63 & 21.50 & 19.63 & 39.25 & - & - & 91.38 & 5.17 & - & - & 3.45 & - \\
\hline
\end{tabular}

Table VI. Latency of the tested groups and of each bird individually for the predator model during memory tests. Time in hundredth seconds.

\begin{tabular}{ccccc}
\hline Rhea & 40 days & 55 days & 70 days & 88 days \\
\hline Group 1 & 28.0 & 148.8 & 24.0 & 95.0 \\
3 & 28.0 & 295.0 & - & - \\
4 & - & 250.0 & 22.0 & 243.0 \\
5 & - & 25.0 & 24.0 & 21.0 \\
7 & 28.0 & 25.0 & 26.0 & 21.0 \\
Group 2 & - & - & 36.5 & 69.0 \\
1 & - & - & 25.0 & 25.0 \\
2 & - & - & - & 206.0 \\
6 & - & - & - & 22.0 \\
8 & - & - & 23.0 & 23.0 \\
Control group & 24.0 & 21.0 & 387.0 & 26.0 \\
\hline
\end{tabular}

\section{DISCUSSION}

The memory capacity of the rheas appeared to be adequate, since the birds responded properly to the predator even three months after the end of the antipredator training sessions. After two memory tests, the control group (untrained group) habituated to the predator model, showing that the antipredator training is necessary to elicit the appropriate behavioural responses in rheas. The trained groups always displayed correct antipredator behaviours up until the last memory test.

According to GRIFFIN et al. (2000), captive-born animals can possess the capacity to express adequate antipredator behaviours but this cannot happen without specific predatory experiences. This hypothesis is confirmed by the results found in this study (differences in the behaviours showed by the trained and untrained groups); some behaviours, like "jumping" to escape from predators and "squatting down and flattening the body against the ground" were never previously observed in $\mathrm{BH}$ Zoo but it were recorded during the antipredator tests.

Rheas responded efficiently to the predator for almost three months. The repetition and the meaning attached to the stimuli received are responsible for the way these information will be stored (MANNING \& DAwKINS 2002). Without doubt, the experience of escaping from a predator has a strong meaning for prey's survival; not only for the individual in question but also to the whole species, since the complex adaptations of predators and counter-adaptations from their preys reflects an evolutionary arm race (KREBS \& DAVIES 1996).

For a reintroduced captive-born animal, to maintain the capacity to recognise a predator for three months is an advantage, since predator-prey encounters have a great probability of occurring within this time period. Antipredator behaviours have a great cost; time and energy wasted avoiding predators could be invested in other activities, such as foraging and reproduction (RYER \& OlLA 1998). This is the reason why antipredator behaviours decrease when the animal is no longer submitted to predation pressure. Living in groups can be advantageous because individuals possess different memory capacities; therefore, the rhea with the greatest memory capacity can serve as a model to other individuals.

The rhea that participated in all memory tests (rhea seven) responded adequately to the predator model, displaying more vigilance behaviours. Rheas four and five, which participated in three tests, also responded appropriately to the predator, exhibiting more defence behaviours (running straight and 
alert); the same result was observed for the birds submitted to two memory tests (rheas one and eight). Rheas submitted to only one memory test (rheas two and six) also showed more vigilance, although the behaviour walking was also expressed (a relaxed behaviour). These results indicate that the rheas did not habituate to the jaguar model.

Three months is a notable time for predator recognition, even for greater rheas, which can live for 20 years in the wild (LeE 1994). However, the maximum time of information storage could not be determined with the present experiment, since the time intervals after the antipredator training sessions were not sufficient for the birds to forget the predator model.

The number of birds in a memory-tested group influenced the behavioural responses of the rheas. Bird seven, for example, changed her behaviour depending on the number of birds being trained with her: in a group of four birds (during antipredator training sessions), she mostly displayed the behaviour walking (a relaxed behaviour); when the group size was reduced to two birds (the two first memory tests), she mostly displayed the behaviour alert (a vigilance behaviour); when tested alone (the two last memory tests), she mostly displayed "running straight" (a defence behaviour) (rhea three, who initially participated of the memory tests with rhea seven, died during the memory tests due to a fight with another rheas in the maintenance enclosure). It is known that life in groups provides to individuals the benefits of protection against predators (HAMMER \& PARRISH 1998, Alcock 1998, Ritz 1998, Lima \& Bednekoff 1999). In small groups, tested rheas changed their behaviours, spending more time in vigilance and less time in relaxing behaviours; this effect is known for wild rheas (Martella et al. 1995, Fernandez et al. 2003) (see Tab. IV). The influence of the number of individuals during antipredator training in terms of behavioural responses of rheas could be tested in a future study.

It is also important to emphasise that social training is ideal for animals that live in groups, such as rheas (SICK 1997) because it is easier for a naive animal to learn how to behave when it has a model to imitate (CURIO 1988, Box \& GIBSON 1999, GRIFFIN \& EVANS 2003).

As in the antipredator training, during the memory tests, trained rheas occupied the area farthest from the predator and pointed their beaks mostly to region one and four, showing that the birds remembered the predator model's appearance, staying "alert" for long periods and running away from it; in the wild, such response would probably be adaptive.

It is interesting to note that the trained birds sustained the vigilance and defence behaviours for almost 15 minutes. after the disappearance of the predator model, even after 70 days after the end of the antipredator training sessions (in the last memory test - 88 days - birds expressed these behaviours for less than 15 minutes). The untrained group initially became frightened when it saw the predator but vigilance and defence behaviours ceased more quickly than in the trained groups.
The results presented in this study showed that the antipredator training could be a useful and cost-effective tool in the recovery program of this species, since the birds possessed a good memory capacity. The next step is to test the effectiveness of this antipredator training memory with reintroduced birds.

\section{ACKNOWLEDGEMENTS}

We would like to thank Dr Andrea Griffin for helping us with the methodologies applied during the antipredator training in this research; to $\mathrm{BH}$ Zoo for the consent to study their animals; to Ângela Bernadete Faggioli and the staff of Bird Section for their help and suggestions. This study was undertaken while Cristiano Schetini de Azevedo was in receipt of a postgraduate scholarship from CAPES (Coordenação de Aperfeiçoamento de Pessoal de Nível Superior). The research conducted in this article conforms to the animal care laws in Brazil and was approved by the Zoo's Ethical Committee.

\section{REFERENCES}

Alcock, J. 1998. Animal Behaviour: an evolutionary approach. Sunderland, Sinauer Associates, 11+759p.

Azevedo, C.S. DE \& R.J. Young. 2006. Behavioural responses of captive-born greater rheas Rhea americana Linnaeus (Rheiformes, Rheidae) submitted to antipredator training. Revista Brasileira de Zoologia, Curitiba, 23 (1): 186-193.

Beck, B.B.; D.G. Kleiman; J.M. Dietz; I. Castro; C. Carvalho; A. Martins \& B. Rettberg-Beck. 1991. Losses and reproduction in reintroduced golden lion tamarins Leontopithecus rosalia. Dodo, Jersey, 27: 50-61.

Box, H.O. \& K.R. Gibson. 1999. Mammalian Social Learning. Cambridge, Cambridge University Press, 438 p.

Codenotti, T.L. \& F. Alvarez. 2000. Habitat use by greater rheas Rhea Americana in an agricultural area of Southern Brazil. Revista de Etologia, São Paulo, 2: 77-84

Codenotti, T.L.; D. Beninca \& F. Alvarez. 1995. Etograma y relacion de la conducta con el habitat y con la edad en el ñandú. Doñana, Acta Vertebrata, Sevilla, 22: 65-86.

CsánYi, V.; G. Csizmadia \& A. MikLosi. 1989. Long-term memory and recognition of another species in the paradise fish. Animal Behaviour, Nottingham, 37: 908-911.

CuRIO, E. 1988. Cultural transmission of enemy recognition by birds, p. 75-97. In: T.R. Zental \& B.G. Galef JR. (Eds.). Social Learning: psychological and biological perspectives. New Jersey, Hilldalf, 368p.

Curio, E.; U. ERnst \& W. Vieth. 1978. The adaptative significance of avian mobbing. Zeitschrift Fur Tierpsychologie, Moscow, 48: 184-202.

DANI, S. 1993. A ema Rhea americana. Belo Horizonte, Fundação Acangaú, 136 p.

Del Hoyo, J.; A. Elliot \& J.A. Sargatal. 1992. A Handbook of the Birds of the World, Volume 1. Barcelona, Lynx editions, 696p. 
Fernandez, G.J.; A.F. Capurro \& J.C. Reboreda. 2003. Effect of group size on individual and collective vigilance in greater rheas. Ethology, Oxford, 109: 413-45.

Ferrari, E.A.M. 1996. Mecanismos neurais de aprendizagem e memória em aves. Campinas, Anais do V Congresso Brasileiro de Ornitologia, UNICAMP, pp. 29-38.

Griffin, A.S. \& C.S. Evans. 2003. The role of differential reinforcement in predator avoidance learning. Behavioural Processes, Dijon, 61, 87-94.

Griffin, A.S.; D.T. Blumstein \& C.S. Evans. 2000. Training captive bred and translocated animals to avoid predators. Conservation Biology, Malden, 14: 1317-1326.

Griffin, A.S.; C.S. Evans \& D.T. Blumstein. 2001. Learning specificity in acquired predator recognition. Animal Behaviour, Nottingham, 62: 577-589.

Hammer, W.M. \& J.K. Parrish. 1998. Is the sum of the parts equals to the whole? The conflict between individuality and group membership, p. 165-172. In: J.K. PARRISH \& W.M. HAMMER (Eds.). Animal Groups in Three Dimensions. Cambridge, Cambridge University Press, 384p.

Herzog, M. \& S. Hopf. 1984. Behavioural responses to species warning calls in infant squirrel monkeys reared in social isolation. American Journal of Primatology, New Orleans, 7: 99-106.

IUCN. 2004. The IUCN Red List of Threatened Species. Available in the World Wide Web at: http://www.redlist.org [accessed on 9.IX.2005].

Kelley, J.L.; J.P. Evans; I.W. Ramnarine \& A.E. Magurran. 2003. Back to school: can antipredatory behaviour in guppies be enhanced through social learning? Animal Behaviour, Nottingham, 65: 665-662.

Kleiman, D.G. 1989. Reintroduction of captive mammals for conservation: guidelines for reintroducing endangered species into the wild. Bioscience, Washington, 39: 152-161.

Krebs, J.R. \& N.B. DAviEs. 1996. Introdução à Ecologia Comportamental. São Paulo, Atheneu Editora, 10+420p.

LEE, A.R. 1994. Ratites: management guidelines for the welfare of zoo animals. London, The Federation of Zoological Gardens, $45 \mathrm{p}$.

Lima, S.L. \& P.A. Bedneckoff. 1999. Back to the basics antipredatory vigilance: can nonvigilant animals detect attack? Animal Behaviour, Nottingham, 58: 537-543.

Maloney, R.F. \& I.G. McLean. 1995. Historical and experimental learned predator recognition in free-living robins. Ani- mal Behaviour, Nottingham, 50: 1193-1201.

Manning, A. \& M.S. Dawkins. 2002. An Introduction to Animal Behaviour. Cambridge, Cambridge University Press, $5^{\text {th }}$ ed., $8+450 p$.

Martella, M.B.; D. Renison \& J.L. Navarro. 1995. Vigilance in the greater rhea: effects of vegetation height and group size. Journal of Field Ornithology, Oklahoma, 56: 215-220.

Mathis, A.; D.P. Chivers \& J.F. SMith. 1996. Cultural transmission of predator recognition in fishes: intraspecific and interspecific learning. Animal Behaviour, Nottingham, 51: 185201.

Mclean, I.G.; C. Holzer \& J.S. Strudholme. 1999. Teaching predator-recognition to a naive bird: implications for management. Biological Conservation, Amsterdan, 87: 123-130.

Miller, B.; D. Biggins; L. Honebury \& A. Vargas. 1994. Reintroduction of the black-footed ferret (Mustela nigripes), p. 455464. In: P.J.S. Olney, G.M. Mace \& A.T.C. Feistner, (Eds.). Creative Conservation. London, Chapman \& Hall, 32+517.

MinekA, S. \& M. Cook. 1988. Social learning and the acquisition of snake fear in monkeys, p. 51-73. In: T.R. ZeNTAL \& B.G. GALEF JR. (Eds.). Social Learning: psychological and biological perspectives. New Jersey, Hilldalf, 368p.

Morgan, P.R. 1972. The influence of prey availability on the distribution and predatory behaviour of Nucella lapillus (L.). Journal of Animal Ecology, Oxford, 41: 257-274.

Perrins, C.M. \& A.L.A. Middleton. 1998. The Encyclopaedia of Birds. New York, Facts of File, 16+63p.

RicHARDS, J. 1998. Return of the natives. Australian Geographic, Terrey Hills, Special edition, 91-105.

Ritz, D.A. 1998. Costs and benefits as a function of group size: experiments on a swarming mysid, Paramesopodopsis rufa fenton, p. 194-206. In: J.K. PARrish \& W.M. Hammer (Eds.). Animal Groups in Three Dimensions. Cambridge, Cambridge University Press, 384p.

Ryer, C.H. \& B.L. Olla. 1998. Shifting the balance between foraging and predator avoidance: the importance of food distribution for a schooling pelagic forager. Environmental Biology of Fishes, Amsterdan, 52: 467-475.

Short, J.; S.D. Bradshaw; J. Giles; R.I.T. Prince \& G.R. Wilson. 1992. Reintroduction of macropods (Marsupialia: Macropoidea) in Australia: a review. Biological Conservation, Amsterdan, 62: 189-204.

SICK, H. 1997. Ornitologia Brasileira. Rio de Janeiro, Editora Nova Fronteira, 862p.

Received in 15.III.2005; accepted in 03.II.2006. 